Article

\title{
Corporate Social Responsibility in the Opinion of Polish and Foreign Students in Management Program of Lublin University of Technology
}

\author{
Barbara Mazur ${ }^{1, *} \mathbb{1}$ and Anna Walczyna ${ }^{2} \mathbb{D}$ \\ 1 Department of Management, Faculty of Management, Lublin University of Technology, 20-618 Lublin, Poland \\ 2 Department of Strategy and Business Planning, Faculty of Management, Lublin University of Technology, \\ 20-618 Lublin, Poland; a.walczyna@pollub.pl \\ * Correspondence: b.mazur@pollub.pl
}

Citation: Mazur, B.; Walczyna, A. Corporate Social Responsibility in the Opinion of Polish and Foreign Students in Management Program of Lublin University of Technology. Sustainability 2021, 13, 333. https:// doi.org/10.3390/su13010333

Received: 21 November 2020 Accepted: 28 December 2020 Published: 31 December 2020

Publisher's Note: MDPI stays neutral with regard to jurisdictional clai$\mathrm{ms}$ in published maps and institutional affiliations.

Copyright: () 2020 by the authors. Licensee MDPI, Basel, Switzerland. This article is an open access article distributed under the terms and conditions of the Creative Commons Attribution (CC BY) license (https:// creativecommons.org/licenses/by/ $4.0 /)$.

\begin{abstract}
The emergence of the Corporate Social Responsibility (CSR) concept resulted in the introduction of the subject to the curricula of management faculties at many universities worldwide. Business schools and management departments educate future decision-makers of the national and global economy. Therefore, in order to be able to anticipate future development trends in the area of CSR, surveys of students' opinions on the responsibilities of business toward society are conducted. This study aimed to answer the question about the way in which students prioritize particular dimensions of CSR. In particular, it focuses on whether the respondents consider the economic dimension to be fundamental, given their different socio-cultural contexts. An additional aim of the research is to verify A. Carroll's original CSR model, as expressed in terms of the economic, legal, ethical, and philanthropic dimensions. The research included two groups of students at the Faculty of Management of the Lublin University of Technology-Polish and foreign. The results obtained in both study groups differ from A. Carroll's original CSR model system. They also differ from each other. In the group of Polish students, the bottom and top dimensions of the pyramid are economic and legal, and in the group of foreign students, they are philanthropic and legal, accordingly. The shapes of the two pyramids are also different, which may be caused by different socio-cultural contexts and specific social needs. The adopted model turned out to be useful for studying the CSR structure expressed in the form of a four-element pyramid. It also allowed the weighting of the perceived importance by the respondents of each individual dimension of CSR. This study helps to predict future corporate social responsibility activities and trends in business.
\end{abstract}

Keywords: CSR; Carroll pyramid; management students; opinions

\section{Introduction}

\subsection{Higher Education Institutions and Education in the Field of CSR}

The importance of Corporate Social Responsibility (CSR) in business reality is constantly growing. Numerous initiatives to support the development of education in CSR have emerged worldwide. In 2007, following the communication of the European Commission entitled "Promoting corporate social responsibility" [1], higher education institutions worldwide have been invited to introduce CSR educational content into their teachings. The initiative has been enhanced by the United Nations Development Program entitled "Accelerating CSR Practices in the New EU Member States and Candidate Countries as a Vehicle for Harmonization, Competitiveness, and Social Cohesion in EU." One of the results was the UN Global Compact initiative, aiming at promoting the six "Principles of Responsible Management Education" (PRME), which are purpose, values, method, research, partnership, and dialogue [2].

In this document, the United Nations state that "academic institutions help shape the attitudes and behavior of business leaders through business education, research, man- 
agement development programs, training, and other pervasive but less tangible activities, such as the spread and advocacy of new values and ideas. Through these means, academic institutions have the potential to generate a wave of positive change, thereby helping to ensure a world where both enterprises and societies can flourish" [3]. In 2019, there were almost 800 signatory institutions to PRME principles. The number represents less than $5 \%$ of the total estimated number of business schools in the world [4].

Higher Education Institutions (HEINS) have been playing an important role in transforming societies through the educational and professional formation of leaders, decisionmakers, entrepreneurs, and scholars who operate in, study, and interpret organizations. In the performance of such a relevant social role, HEINS have been considering issues that involve sustainability and sustainable development, as well as CSR [5]. The formal educational system is considered to be an appropriate arena to promote ERS because it can shape the views and attitudes of students towards sustainability and contribute to a profound social change [6]. If higher education students are to become the future members of the corporate universe, as well as the decision-makers in a society, and their understanding will have a significant effect on a country's future, it is not only relevant but crucial to come to know their opinions regarding Corporate Social Responsibility (CSR).

As already noted, the importance of CSR in today's business reality is constantly growing, hence the increasing educational effort of universities, and in particular, business schools, in promoting it in the curricula. The sources of this effort and increased interest have been studied by G. Fornes et al. [4]. They conducted a study of the Master of Business Administration (MBA) programs in Asia, Latin America, and Southern Europe to gain insight into how ethics, responsibility, and sustainability are incorporated into MBA education. The results of their research prove that CSR-related courses shape the awareness of social responsibility among MBA graduates, who, as a consequence, modify their career goals. They also showed that both the international accreditation process and the expectations of employers regarding MBA graduates having the ability to conduct socially responsible activities and apply appropriate CSR methods and tools in practice can play an important role in promoting CSR courses in business schools. Although the number of studies investigating social responsibility courses and programs, as well as the intentions of universities to involve in CSR activities in higher education institutes all over the world, is constantly growing [7-12], with regard to universities operating in Poland, such studies are relatively scarce and their scope is limited [2,13]. When discussing the topic of teaching CSR in Polish universities, the authors more often mention those universities that have introduced this subject to their programs and present the students' assessment of the teaching process itself rather than the opinions of students on understanding the importance of CSR in the activities of enterprises and social needs in this regard [13].

Since the way managers deal with the dilemmas in the corporate universe has consequences not only for organizations but also for society as a whole, it is worth knowing their priorities in relation to areas of social responsibility. Knowledge on this subject will help to determine which activities should be expected in the near and distant future, when, after graduation, graduates of management studies will begin to play managerial roles in enterprises and undertake CSR activities. Transposing the attitudes of students to the attitudes of managers seems to be largely legitimate, as evidenced by the research results, as the similarities and differences between managers and business students, with respect to CSR, have been widely studied [14].

A. Carroll's model has not been used so far in surveys of Polish students' opinions on CSR. As it has already been used in surveys among students in other countries, the novelty of this study lies in testing the model in a new context. This context is unique, as it enables the study of Polish students' perceptions of CSR and how they compare to those of foreign students. The results of the study placed in such a context may contribute to the expansion of the theory on the conceptualization of CSR expressed by A. Carroll's pyramid, confirming that the type of dimensions in the pyramid is constant, but their arrangement is not. 


\subsection{Current State of Research}

Academic interest in investigating the significance of CSR in the context of HEINS and among the student population is not new. The results of numerous studies emphasize the importance of CSR and stakeholder theory in managerial education, and the development of issues related to social responsibility within university programs has been considered necessary in the process of educating future leaders, managers, and entrepreneurs [15-20]. The research conducted so far covers a wide range of issues related to the concept of CSR. In relation to students of management (bachelor's and master's levels) and business school students, the research covered, among others includes the following: knowledge of the CSR concept itself, sources of knowledge about the concept, the level of needs and willingness to expand it, the evaluation of classes devoted to this subject and the sociodemographic determinants of the perception of CSR. The research area is also very diverse, as it has covered students of management at one university in a selected country, at many universities in one country, as well as a comparative study involving students from several countries.

An example of research conducted at one university is the research conducted at the Faculty of Management and Economics at the Gdańsk University of Technology [2]. The research was conducted in the academic year 2014/2015 on a sample of 693 students. The sample was composed of bachelor or engineering students of management. Research has shown that there is a discrepancy in the program's adopted content, and the students assessments of the level of CSR education turned out to be quite low. The research results demonstrated that, despite the fact that most students did not participate in a specific course on CSR, many of them were introduced to this topic embedded in other academic courses. At the same time, they would like to develop their knowledge of CSR mostly by participating in a tailored CSR project, based both in a real company or the university.

Another example of research conducted in one university is the research conducted in Portugal [19]. The study was conducted on a sample of 194 students from the Porto Polytechnic. Researchers, recognizing that CSR is an essential topic for higher education institutions, conducted a study aimed at identifying the perceptions of CSR by students and examining whether sociodemographic variables (such as gender, age, work experience, and academic degree) influence the perception of CSR. The results obtained in the study suggest that, in line with how students perceive CSR, they can be divided into "pro CSR", "resistant to CSR", or "assigning CSR a secondary importance", while sociodemographic variables did not turn out to be significantly differentiating the perception of CSR by the surveyed students.

Also noteworthy is the study by M. Larrán et al. [21], who analyzed the attitudes of Spanish students of business and accounting toward Corporate Social Responsibility. There were 319 correctly completed questionnaires obtained in the study. The results show that the surveyed business and accounting students displayed greater concern about the social and environmental dimensions of CSR than the students surveyed in previous research using the same research tool. The latter (previously surveyed) showed a stronger attachment to the economic dimension of the concept of Corporate Social Responsibility and sustainable development than the students surveyed later. These differences are supported by cultural, socio-economic, and legal factors, as well as the institutional commitment of the university.

An example of a study conducted at many universities operating in one country is the study conducted by D. Ććkalo et al. [22]. They examined the opinions of business students on the relationship between CSR and competitiveness. The research, conducted over a period of five years, covered over 3300 students at universities and business schools in 22 cities and municipalities in Serbia. The obtained results show that many of the respondents did not know the concept of CSR and, therefore, did not include it among the factors lacking in the development of the competitiveness of the Serbian economy.

In addition to the CSR studies focused on one national group, comparative studies were also carried out covering a larger representation of national groups. Examples 
of comparative studies include studies conducted at universities in Canada and Mexico, and studies at universities in Spain, Bulgaria, and Poland. The research first mentioned was aimed at identifying the similarities and differences in CSR programs and the way social responsibility is taught at Mexican and Canadian universities. In search of similarities and differences, researchers conducted six interviews with university officials and academics teaching CSR at a Mexican university and eight interviews at a Canadian university [16]. The main conclusions of their research are the following: Mexico's CSR program is seen as a strategic management tool that adds value to the organization. However, it does not take into account the context of globalization. In Canada, social responsibility is based on ethics; there is an emphasis on different stakeholders in a globalized environment, and the strategic importance of CSR is widely accepted. Despite the fact that the survey participants were academics and representatives of university authorities, and not students, their approach to CSR may at least, to some extent, be related to the students of these HEINs.

The study mentioned second was a study of which the results provide insight into the cultural determinants of understanding Corporate Social Responsibility [14]. The study was conducted at business schools at universities in Spain, Poland, and Bulgaria in 2011/2012 and covered 1074 students (including 350 students from Poland). The analysis of the results showed that both the structure of value preferences and the perceptions of CSR by students are influenced by cultural factors. The study revealed a different approach to CSR in these three European countries. The national context influences the system of values, which in turn influences the general perception of CSR and the level of acceptance of activities in individual areas of CSR. The research conclusion was that the clear impact of national cultures on the attitudes toward social responsibilities will have to be taken into account by companies when defining their CSR policies and communicating to stakeholders in different countries. The topic of the influence of values on the perception of CSR was also included in the article by N. Farcane et al. [23], in which the assessment of the level of CSR integration with corporate identity was discussed.

When considering comparative studies, it is worth mentioning a study by D. HaskiLeventhal [24], whose research focused on responsible management attitudes and was carried out amongst graduate students enrolled in business and management programs. The research included students from numerous countries from five continents: North America, South America, Europe, Asia, and Australia. In total, 1285 students were surveyed. The obtained research results suggest that MBA students demonstrate social awareness and display a positive attitude towards the notions of CSR and responsible management education. Moreover, the research also showed that its respondents regarded social values highly and were community-orientated, which was channeled via volunteering and financial donations.

\subsection{CSR Conceptualization}

This paper analyzes the opinions of Polish and incoming Erasmus+ students of management at the Lublin University of Technology, regarding the notion of CSR. The research sample consisted of management students, who, due to the specific character of their education, will prospectively manage organizations or become entrepreneurs, that is, they will become responsible for setting the trends for the development of organizations. The survey was conducted after the end of the semester of CSR classes.

This study aimed to answer the following research questions: How do the surveyed students prioritize the various dimensions of CSR, and in particular, which dimension (economic, legal, ethical, or philanthropic) is considered fundamental by them? Is the set of dimensions universal (conceptualization, according to Carroll's definition)? Is the basis always the economic dimension or is the order of dimensions dependent on the sociocultural context of the studied students? Through the study, it was possible to verify the CSR model built by A. Carroll in its original version in 1991 [25]. The study was conducted among two student populations (students from Poland and students from the Erasmus + program) and facilitated the search for answers as to whether it is useful for this type of 
research in its original form, and whether it allows the weight of individual dimensions to be determined depending on the country of origin of the students.

Despite the general goal of investigating the issue of CSR among the target population, constituted by higher education students, this particular study fills a different research gap in comparison with the two aforementioned examples by the characteristics of the national context. This study explores the context of Polish and Mediterranean countries, such as Spain and Italy. The discussions about CSR are anchored in the stakeholder theory, which states that by analyzing the relationship between an organization and (individual or collective) social actors, the complexity of the corporate universe is easier to deconstruct. To approach this complexity, O. Falck and S. Heblich [26] maintain that CSR may be strategically used to meet the specific needs of the stakeholders. Therefore, it could achieve satisfactory results for all: organizations, businesses, and society; both in the present and in the future. The conceptual perspective of the CSR pyramid proposed by A. Carroll [25] has been widely studied in higher education management programs. It has also been acknowledged by business and academic circles. According to A. Carroll $[25,27]$, an organization's CSR comprises four complementary dimensions, which together constitute CSR. Those four dimensions are organized in the form of a hierarchy, taking the shape of a pyramid with the economic dimension at its base. The legal, ethical, and philanthropic dimensions follow, respectively. A. Carroll [25] states that the economic and legal dimensions symbolize the social demand of businesses. The ethical dimension resonates with society's expectancies of a business, while the philanthropic dimension reflects what society "expects/desires" of a business. The CSR pyramid is illustrated in Figure 1.

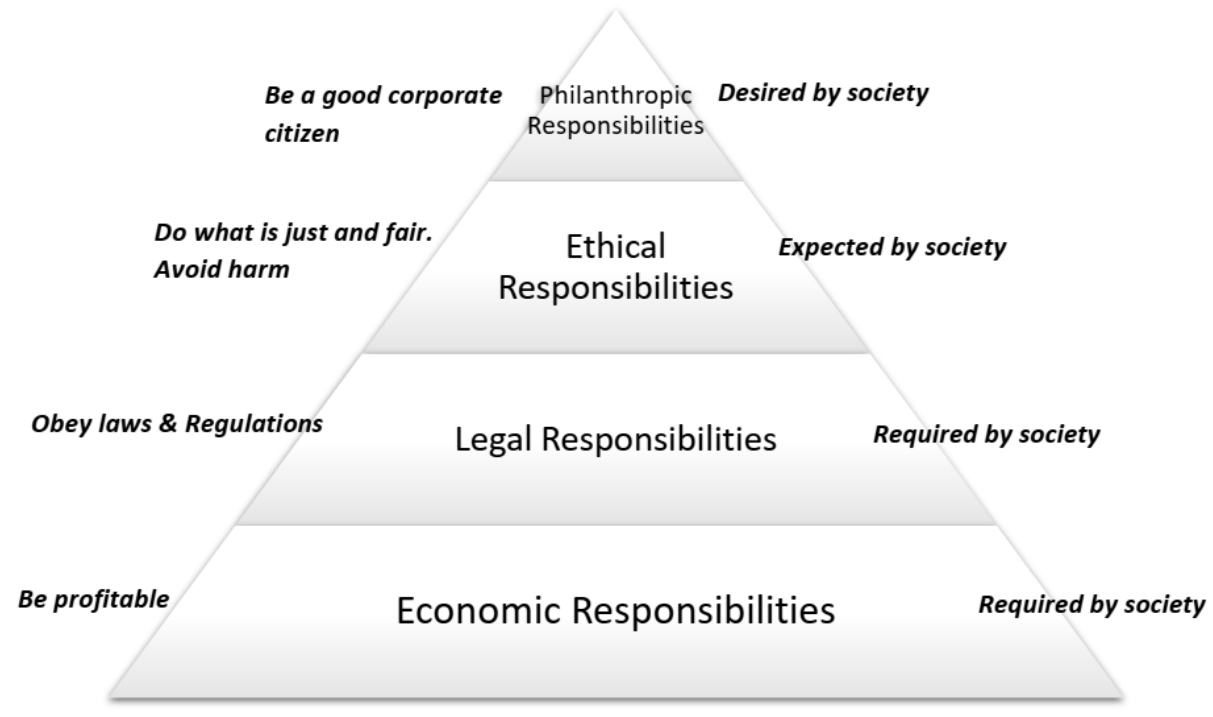

Figure 1. The CSR Pyramid.

As per A. Carroll, the economic dimension lies at the base of the pyramid, and therefore, it predicates all other dimensions. To be productive and profitable, to be able to meet the consumption need of the market (society), and to fill the expectations of providing a return on investment are the organization's goals. It forms the base from which all other organizational roles or commitments derive. Within the legal dimension is the lawthe moral and ethical values of a society in a codified form, the indicator of right and wrong for its members. In that sense, within an organization's economic mission is the commitment to uphold legal standards, to conform to the standards, and comply with the legislation issued by the public bodies [25]. Within the ethical dimension lies a further commitment to society's moral values, to do the right thing even when a situation or behavior is not particularly legally regulated. In that sense, this dimension considers values and principles defined, upheld, and cherished as acceptable or desired by society [25]. Finally, the philanthropic dimension represents all the actions taken by an organization to 
respond to society's expectation that organizations should be role-model corporate citizens. Hence, this is where the expectation for an organization to be engaged in social discourse and life quality improvement stems from, by articulating legal, ethical, and economic responsibilities, as well as adopting philanthropic practices [25].

Although the CSR pyramid has evolved over the years $[27,28]$, the original model proposed by A. Carroll was applied in this study. It served as theoretical guidance in the procedures of data collection and analysis for the purpose of this research. Therefore, it constitutes the research model. The use of this model was justified by its wide application in the context of professional education of undergraduate management students. Moreover, the original model has already been used by researchers in several studies, as suggested by F. Lyra et al. [29], F. Almeida [30], and, regarding the model's previous version, by K. Aupperle et al. [31].

\section{Materials and Methods}

\subsection{Research Population}

The research involved master's students of management. The first group constituted students at the Lublin University of Technology (Poland) and the second group was made up of students studying at the Lublin University of Technology under the Erasmus+ program (exchange). The Polish group consisted of 61 people (the total number of full-time students), including 45 women and 16 men. The exchange group was very diverse in terms of nationality. Hence, the research covered all those who studied at the Lublin University of Technology at the time of the research and belonged to a relatively homogeneous group. It was composed of students from France, Spain, Portugal, and Italy, with a total of 30 students, including 16 women and 14 men.

The subject of CSR was not unknown to the respondents, as everyone in the research group participated in the CSR classes. The classes lasted $45 \mathrm{~h}$ in total, including $15 \mathrm{~h}$ of lectures and $30 \mathrm{~h}$ of exercises. The aim of the course was for students to acquire knowledge about the essence of Corporate Social Responsibility, its role and importance in social life. The class also aimed at shaping the attitudes of socially responsible future managers, as well as developing the ability to apply knowledge to identify problems in the field of CSR and solve them. Issues undertaken during the course included the following:

- Corporate Social Responsibility (CSR) - a historical line, definition, contemporary recognition, models and standards of social responsibility; CSR conditionings and its perception in Poland

- $\quad$ Basic models of social responsibility; the stakeholders-CSR theory; Stakeholder management in the strategic management system of the company; the dispute over corporate social responsibility-CSR and PR

- $\quad$ Responsible corporate management-wide and narrow view

- $\quad$ Personnel management and CSR; conflict of interests and the employees' and organization's responsibilities; Human Rights as a basic responsibility toward the employees; institutionalization of ethics in management

- One's moral choices in consumer culture; modern ethical standards of the consumer culture

- Environmental responsibility

- $\quad$ Reporting as an important element of CSR strategy in organizations; social responsibility as a source of competitive advantage

- A company's development as a process of creating value for stakeholders

- Participation in CSR classes was undoubtedly conducive to in-depth reflection while filling in the questionnaires, and the method of constructing the research tool also highlighted the dilemmas faced by managers.

To sum up, the respondents constituted a group that was, in some respects, homogeneous and, in other respects, diverse. Common features were age, field of study, and participation in the CSR class. Origin was the most important differentiating feature. 
On this basis, two groups were distinguished, conventionally called the Polish group and the Erasmus group.

\subsection{Research Tool}

The survey technique was used in the research. The questionnaire was based on A. Carroll's model, according to which, CSR is a construct that includes economic, legal, ethical, and philanthropic components [32]. Developed by K. Aupperle, J. D. Hatfield, and A. Carroll [31], the research tool was modified for the research of Brazilian management students $[5,15]$. The tool consists of 64 statements ( 16 for each CSR dimension), divided into 16 groups (G1-G16), each of which contains 4 statements-one for each of the components of CSR, with each statement referring to a specific group of stakeholders. Therefore, the applied research tool was reflective, that is, it was assumed that there are four dimensions of CSR and the reliability of the study was checked using factor analysis. To evaluate the statements included in a given group, a scale of constant sums was used [33]. This means that the respondents were asked to divide a fixed sum of points (10) between four statements. In this way, they determined the relative importance of individual statements referring to the examined components. The questionnaire also contained personal characteristic questions, such as the gender and nationality of the respondents.

\subsection{Selection and Application of Statistical Methods}

The analysis of the collected data began with checking the reliability of four CSR scales. For this purpose, Cronbach's alpha coefficients were calculated and factor analysis was performed. The correlation coefficients between the individual dimensions of CSR (Spearman's rank correlation coefficient) were also checked. In the next step, the average for each of the CSR dimensions was calculated-separately for the Polish group and Erasmus students. For this purpose, aggregated data was created for each CSR dimension (the sum of points assigned to statements included in a given dimension). Then, using the Student's $t$-test for independent samples, the significance of differences in the assessment of the importance of the dimensions constituting individual steps in Carroll's pyramid was checked. The null hypothesis about the lack of differences between the means in the tested pairs of CSR dimensions was tested. By carrying out the $t$-test, the assumption of homogeneity of variance (Levene's test) was also checked. If the condition was not met, the Cochran-Cox test was performed. On this basis, the structure of the CSR pyramid for each study group was established. A significance level of 0.05 was assumed for both tests. Correlation coefficients between the individual dimensions of CSR (Spearman's rank correlation coefficient) were also calculated. All calculations were made using the STATISTICA 13.1 statistical package.

The value of Cronbach's alpha coefficients for individual scales in the group of Polish students was 0.80 for the economic dimension, 0.71 for the legal dimension, 0.64 for the philanthropic dimension, and 0.35 for the ethical dimension. Since the Cronbach's alpha coefficient for the philanthropic dimension turned out to be slightly lower than the required minimum; and for the ethical dimension it was much lower, factor analysis was performed. It showed the existence of a clearly separated economic factor, which additionally included the philanthropic aspect. The second clearly distinguishing factor was the legal aspect. The third factor was not clearly distinguished (low factor loadings). Moreover, the ethical dimension with high factor loadings also appeared in factors 1 and 2.

In order to check whether the division into four dimensions was justified using factor analysis, the clustering of dimensions in all three factors was checked altogether using cluster analysis. Due to the fact that the factor loadings are real values, the k-means cluster analysis method with the Euclidean metric was applied. This method was used because it can be used to check the position of factor loadings in three factors at once. In the case of division into four groups, groupings were obtained, wherein each group one aspect constituted most of the elements. In the case of division into three groups, no clear grouping was obtained. Consequently, it was decided to distinguish four dimensions 
of CSR, analogous to the studies by K. Aupperle, J. D. Hatfield, and A. B. Carroll [31], and A. da Silva Junior et al. [5,15]. This procedure was also dictated by the desire to compare the results with the results obtained by Brazilian researchers. This will enable a broader perspective on CSR perception by students. This is important because management departments educate future decision-makers in the national and global economies.

\section{Results}

\subsection{The CSR Pyramid Layout for the Polish Student Group}

The research adopted the CSR concept proposed by A. Carroll, and therefore, analyses that will allow for its reconstruction in the study group were carried out.

The means obtained in each CSR dimension are shown in Table 1. The highest results were obtained in the financial and ethical dimensions. Means obtained in the legal and philanthropic dimensions were similar.

Table 1. Means in individual CSR dimensions in the Polish student group.

\begin{tabular}{ccc}
\hline Dimension & Mean & Hierarchy \\
\hline Economic & 42.88 & 1 \\
Legal & 37.84 & 4 \\
Philanthropic & 38.17 & 3 \\
Ethical & 41.16 & 2 \\
\hline
\end{tabular}

In order to check if particular dimensions differ from each other, the Student's $t$-test was performed for the dependent samples (Table 2). The null hypothesis stating that the compared pairs of means do not statistically significantly differ was tested and compared to the alternative hypothesis that the observed differences are statistically significant.

Table 2. The values of the $t$-test for paired samples for two-sided comparisons for the Polish student group.

\begin{tabular}{cccc}
\hline Dimensions & $\mathbf{t}$ & $\mathbf{d f}$ & $\mathbf{p}$ \\
\hline Economic vs. Legal & 2.711 & 120 & $0.00769^{*}$ \\
Economic vs. Ethical & 1.007 & 120 & 0.31615 \\
Economic vs. & 2.615 & 120 & $0.01000^{*}$ \\
Philanthropic & -2.391 & 120 & $0.01837^{*}$ \\
Legal vs. Ethical & -0.219 & 120 & 0.82664 \\
Legal vs. & & 120 & $0.02424^{*}$ \\
Philanthropic & 2.282 & & \\
Ethical vs. & &
\end{tabular}

* statistically significant differences.

The conducted analyses allow for the presentation of the CSR pyramid in the group of Polish students (Figure 2). Visible gaps between individual dimensions mean that the differences between them are statistically significant. The partial overlapping of individual layers means that these differences are not statistically significant.

In comparison to the adopted research model in the form of Carroll's pyramid, the system of dimensions in the case of the studied group is different, except for the economic dimension, which in both cases comprises the very basis of the pyramid.

\subsection{The CSR Pyramid Layout for the Erasmus Students Group}

The analysis of the CSR pyramid structure in the group of Erasmus students also started with the presentation of the means obtained in each dimension (Table 3). The philanthropic dimension mean was the highest, while the financial and ethical dimension means were slightly lower. The legal dimension was the lowest. 
Philant

hropic

\section{Ethical}

\section{Economic}

Figure 2. CSR pyramid layout for the group of Polish students.

Table 3. Means in individual CSR dimensions in the Erasmus student group.

\begin{tabular}{ccc}
\hline Dimensions & Mean & Hierarchy \\
\hline Economic & 40.77 & 2 \\
Legal & 36.53 & 4 \\
Philanthropic & 41.83 & 1 \\
Ethical & 40.57 & 3 \\
\hline
\end{tabular}

To check the significance of differences between individual CSR dimensions, twosided comparisons using the $t$-test against the variable were made (Table 4). The tested hypotheses (zero and alternative) were the same as in the Polish group.

Table 4. The values of the $t$-test for paired samples for two-sided comparisons for the Erasmus student group.

\begin{tabular}{cccc}
\hline Dimensions & $\mathbf{t}$ & $\mathbf{d f}$ & $\mathbf{p}$ \\
\hline Economic vs. Legal & 1.882 & 58 & 0.06488 \\
Economic vs. Ethical & 0.084 & 58 & 0.93306 \\
Economic vs. & -0.430 & 58 & 0.06688 \\
Philanthropic & -2.181 & 58 & $0.03323^{*}$ \\
Legal vs. Ethical & -2.666 & 58 & $0.00992^{*}$ \\
Legal vs. & & 58 & 0.55329 \\
Philanthropic & -0.596 & & \\
Ethical vs. & & &
\end{tabular}

* statistically significant differences.

The conducted analyses allow for the presentation of the CSR pyramid layout for the group of Erasmus students (Figure 3).

In comparison to the adopted research model in the form of A. Carroll's pyramid, the system of dimensions in the case of the studied group is different, except for the ethical dimension, which in both cases constitutes the third layer of the pyramid.

\subsection{The Correlations between CSR Dimensions in the Group of Polish and Erasmus Students}

On the basis of the obtained data, the Spearman's rank correlation coefficients between individual CSR dimensions were also calculated. The results for the group of Polish students are presented in Table 5. 


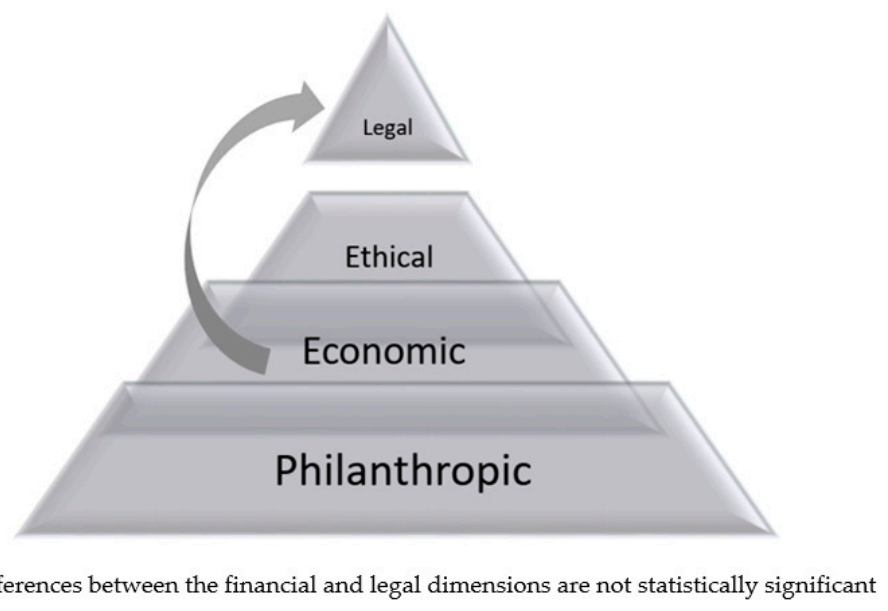

Figure 3. CSR pyramid layout for the group of Erasmus students.

Table 5. Correlation coefficients between the CSR dimensions for Polish students.

\begin{tabular}{ccccc}
\hline Dimensions & Economic & Legal & Philanthropic & Ethical \\
\hline Economic & 1 & & & \\
Legal & -0.25 & 1 & & \\
Philanthropic & $-0.68^{*}$ & $-0.30^{*}$ & 1 & 1 \\
Ethical & $-0.54^{*}$ & $-0.42^{*}$ & $0.41^{*}$ & 1 \\
\hline
\end{tabular}

$* p<0.05$. Note: Interpretation of the obtained values of the correlation coefficient: $\mathrm{r}<0.3$, weak correlation $\mathrm{r}<0.5$, moderate correlation; up to $\mathrm{r}<0.7$, high correlation; to $\mathrm{r}<0.9$, very high correlation; $\mathrm{r}<1$, the correlation is almost complete [34].

High negative correlation coefficients were observed between the philanthropic, ethical, and economic dimensions, and a moderate negative correlation between the ethical, philanthropic and legal dimensions. Moderate positive correlation occurs between the ethical and philanthropic dimensions.

In relation to the group of Erasmus students, strong and moderate correlations were also observed between the dimensions of CSR, but there were fewer of them (Table 6).

Table 6. Correlation coefficients between the CSR dimensions for Erasmus students.

\begin{tabular}{ccccc}
\hline Dimensions & Economic & Legal & Philanthropic & Ethical \\
\hline Economic & 1 & & & \\
Legal & -0.05 & 1 & & \\
Philanthropic & $-0.36^{*}$ & $-0.63^{*}$ & 1 & 1 \\
Ethical & $-0.66^{*}$ & -0.18 & 0.01 & 1 \\
\hline
\end{tabular}

$* p<0.05$. Note: Interpretation of the obtained values of the correlation coefficient: $\mathrm{r}<0.3$, weak correlation; $\mathrm{r}<0.5$, moderate correlation; up to $\mathrm{r}<0.7$, high correlation; to $\mathrm{r}<0.9$, very high correlation; $\mathrm{r}<1$, the correlation is almost complete [34].

High negative correlation occurred between the ethical and economic, as well as philanthropic and legal dimensions, and a moderate one between the philanthropic and economic dimensions.

When comparing the correlation coefficients between the Polish and Erasmus groups, both similarities and differences can be observed. The similarity concerns the correlation between the ethical and economic dimensions-strong negative correlations in both groups. In the Polish group, a moderate correlation was observed between the ethical and philanthropic dimensions. In the group of Erasmus students, no such correlation occurred. 


\section{Conclusions and Discussion}

The conducted analyses lead to the conclusion that A. Carroll's pyramid model is useful in examining students' perceptions of the role of CSR in the functioning of enterprises. This is especially important for students of management who will be responsible for the way an organization functions in the environment. In this context, it should be noted that by the surveyed students from the Polish group, the issues of ethics and profit, as well as promoting civic attitudes and profit, are perceived, to a large extent, to be contradictory (Table 5). In the group of Erasmus students, profit and ethics are also perceived as largely antagonistic, the other pair being the legal and philanthropic dimensions (Table 6). Aupperle, Hatfield, and Carroll [31] indicate that the CSR model consists of economic and social responsibility (the remaining three dimensions), and therefore, the economic dimension should negatively correlate with the others. In the presented studies, such correlations were not obtained in all cases. In this context, it is worth noting that in the group of Polish students, a negative correlation was observed between the economic and legal dimensions, while in the group of Erasmus students, there was basically no correlation (-0.05). This may indicate that the Erasmus student group is more aware that it is impossible to pursue economic goals without respecting the law. These findings seem to confirm the assumption about the cultural conditioning of CSR and mark the way toward a new theoretical model of CSR, in which the legal dimension moves away from the ethical and philanthropic one and comes closer to the economic one. This finding is also a valuable premise in the design of curricula. The results obtained in the study fit into the broader context of research based on A. Carroll's CSR model. This group includes studies conducted in Brazil and African countries.

Despite the fact that the scope of the conducted research does not allow for an unambiguous interpretation of the obtained results, they may build a valuable premise for designing curricula.

The specificity of the context of the presented research is that from the end of World War II to 1989, when Poland belonged to the camp of socialist countries whose centrally planned economies resulted in a low income for the population. Poland's accession to the EU in 2004 highlighted the existing differences between countries such as Poland and other countries continuously operating in the free market. The differences in income and living standards in the countries of the former socialist camp compared with other countries are steadily decreasing, but the equalization of levels is not expected until several decades from now. Integration with other countries within the EU has highlighted the existing differences and, therefore, the economic dimension of CSR in Poland is perceived as a priority, all the more so as Poland is commonly perceived as a region of cheap labor for more economically developed countries.

Within this study, the detailed results of the groups of Polish and Erasmus students were not compared. The focal point was rather the layout of the CSR pyramid, the arrangement of individual layers and the differences in the assessment of individual dimensions. Assuming the usefulness of Carroll's CSR concept, it was observed that the arrangement of individual layers is not universal. In the case of the Polish student group, the differences in the assessment of the importance of individual dimensions are quite clear, and the structure is more hierarchical. In the case of the Erasmus student group, the pyramid seems to be flattened, with the individual dimensions partially overlapping. The two groups also differ when it comes to the arrangement of individual dimensions (Figures 2 and 3). The observed difference may result from the socio-economic context and needs specific to a given place and time.

Organizations operate in a specific environment that they not only affect but must also adapt to. Both groups of respondents were subjected to the same educational impact in the field of CSR, but they differed in origin. It seems that this factor may have contributed to the structure of the CSR pyramid specific for each group. Such conclusions are also prompted by studies among Brazilian management students, as a result of which, the authors obtained an inverted pyramid in relation to the one proposed by A. Carroll [15]. The results proved 
that, in the opinion of the surveyed students, the most important dimensions of CSR are, in hierarchical order, the philanthropic, ethical, legal, and economic dimensions. This was also confirmed by the research of W. Visser [28], who applied Carroll's model in the study of African countries. The findings suggested that Carroll's notion of CSR was not global. Conversely, it seems that the concept of CSR could depend on varied national contexts. The obtained results indicate the hierarchical order of the CSR pyramid, with the economic dimension at its base, and followed by the philanthropical, legal, and ethical dimensions, respectively.

Research using A. Carroll's CSR model in developing African countries has proven the greatest importance attached to the economic dimension. Poland, unlike African countries, belongs to a group of developed countries. However, due to many years of functioning in a centrally controlled economy characterized by market shortages and low incomes of employees, it values the economic dimension analogically. The results obtained in the study of PL management students' opinions confirm the validity of the basic assumption of A. Carroll's model regarding the location of this dimension in the structure of the CSR pyramid. It should be emphasized, however, that this assumption applies especially to countries whose economies are considered to be developing, not developed. Moreover, it should be admitted that the system of dimensions, apart from the level of economic development, may also be influenced by other factors (e.g., cultural), which were not analyzed in this article.

In Poland so far, there has been no similar research among students in the field of management. This indicates the existence of an insight gap about their perception of CSR from the Carroll pyramid perspective. The sparse studies conducted in recent years also indicate a lack of knowledge about CSR. E. Jastrzębska [13], referring to the study "CSR through the eyes of students", carried out by students at the Warsaw School of Economics (SGH) in seven universities in the country, confirms this statement. Out of 1260 students of different years, only $30 \%$ declared knowledge of the CSR concept, and only one-third confirmed that their university provides opportunities to deepen the knowledge on this subject, while as many as $84 \%$ of respondents would like to learn about CSR. The deficit of knowledge about the perception of CSR by students is also proven in a study by M. Popowska [2]; $57.5 \%$ of students did not take any course on social responsibility. The data offer a rather polarized evaluation of the quality of CSR teaching: $52.5 \%$ of students qualified it as average or above average (good or very good), against $46 \%$ who assessed it as poor or even very poor.

The study has its limitations, the main of which is that the study covered students of one course at the Faculty of Management of the Lublin University of Technology. Moreover, the group of Erasmus students who participated in the study was not a homogeneous group in terms of nationality. As one of the suggestions for further research, it could be carried out on a larger research group at the Lublin University of Technology itself, as well as at its Erasmus-partnered universities. In this context, the research presented in the article would be a pilot study.

Yet another suggestion is to extend this research geographically so that it reaches all universities conducting management studies across the region, and even nationwide.

In the context of the SARS-CoV-2 epidemic, it would also be worth conducting comparative studies on the perception of CSR by students in the pre- and post-pandemic periods.

We present the results of the study for the consideration of business managers so that, in order to gain the trust of stakeholders, they effectively manage CSR [35], thus creating a better, more fair and responsible society.

Author Contributions: Both authors (B.M. \& A.W.) confirm that their contribution in each stage of the preparation of this article was equal. Both authors have read and agreed to the published version of the manuscript.

Funding: This research received no external funding. 
Institutional Review Board Statement: Not applicable.

Informed Consent Statement: Not applicable.

Conflicts of Interest: The authors declare no conflict of interest.

\section{References}

1. European Commission. Communication from the Commission to the European Parliament, the Council, the European Economic and Social Committee and the Committee of the Regions A Renewed EU Strategy 2011-14 for Corporate Social Responsibility: A Renewed EU Strategy 2011-14 for Corporate Social Responsibility. Available online: https: / eur-lex.europa.eu/LexUriServ / LexUriServ.do?uri=COM:2011:0681:FIN:EN:PDF (accessed on 15 November 2020).

2. Popowska, M. CSR Education in Poland-Current Situation and Future Challenges. Horyz. Wych. 2016, 15, 87-101. [CrossRef]

3. UN Global Compact. The Principles for Responsible Management Education (PRME). Available online: https://d306pr3pise04h. cloudfront.net/docs/news_events\%2F8.1\%2FPRME.pdf (accessed on 15 November 2020).

4. Fornes, G.; Monfort, A.; Ilie, C.; Koo, C.K.; Cardoza, G. Ethics, Responsibility, and Sustainability in MBAs. Understanding the Motivations for the Incorporation of ERS in Less Traditional Markets. Sustainability 2019, 11, 7060. [CrossRef]

5. da Silva Junior, A.; de Oliveira Martins-Silva, P.; de Araújo Vasconcelos, K.C.; Correa da Silva, V.; Martins Silva de Brito, S.L.; Rocha Monteiro, J.M. Sustainability and corporate social responsibility in the opinion of undergraduate students in management programs: Between the concrete and the abstract. J. Clean. Prod. 2019, 207, 600-617. [CrossRef]

6. Dobson, A. Environmental citizenship: Towards sustainable development. Sustain. Dev. 2007, 15, 276-285. [CrossRef]

7. Adler, N.J.; Gundersen, A. International Dimensions of Organizational Behavior; Recording for the Blind \& Dyslexic: Princeton, NJ USA, 2007; ISBN 978-0324360745.

8. Christensen, L.J.; Peirce, E.; Hartman, L.P.; Hoffman, W.M.; Carrier, J. Ethics, CSR, and Sustainability Education in the Financial Times Top 50 Global Business Schools: Baseline Data and Future Research Directions. J. Bus. Ethics 2007, 73, 347-368. [CrossRef]

9. Evans, F.J.; Marcal, L.E. Educating for Ethics: Business Deans' Perspectives. Bus. Soc. Rev. 2005, 110, 233-248. [CrossRef]

10. Hill, R.P. The Socially-Responsible University: Talking the Talk while Walking the Walk in the College of Business. J. Acad. Ethics 2004, 2, 89-100. [CrossRef]

11. Mahoney, J. Teaching Business Ethics in the UK, Europe, and the USA. A Comparative Study; Athlone Press: London, UK, 1990; ISBN 0485113996.

12. Matten, D.; Moon, J. Corporate Social Responsibility Education in Europe. J. Bus. Ethics 2004, 54, 323-337. [CrossRef]

13. Jastrzębska, E. Uczelnie wyższe a edukacja w zakresie społecznej odpowiedzialności biznesu. Available online: http: / / bazhum.muzhp.pl/media / / files/Zarzadzanie_Zmianami_zeszyty_naukowe/Zarzadzanie_Zmianami_zeszyty_naukower2010-t-n2/Zarzadzanie_Zmianami_zeszyty_naukowe-r2010-t-n2-s1-13/Zarzadzanie_Zmianami_zeszyty_naukowe-r2010-tn2-s1-13.pdf (accessed on 15 November 2020).

14. González-Rodríguez, M.R.; Díaz-Fernández, M.C.; Pawlak, M.; Simonetti, B. Perceptions of students university of corporate social responsibility. Qual. Quant. 2013, 47, 2361-2377. [CrossRef]

15. da Silva Junior, A.; de Oliveira Martins-Silva, P.; Feu, K.S.; Komino, A.C.; da Silva, V.C.; de Araújo Vasconcelos, K.C. Corporate social responsibility in the perspective of Brazilian management students: The inversion of the pyramid. SRJ 2018, 16, 50-72. [CrossRef]

16. Gonzalez, S.; Erogul, M.S.; Barragan, S. Similarities and differences in teaching corporate social responsibility: Evidence from Mexico and Canada. Eries J. 2016, 9, 70-80. [CrossRef]

17. González-Gómez, S. Teaching CSR at Management Faculties: The Touchstone Strategy for Organizations' Management Challenge. In Strategy, Power and CSR: Practices and Challenges in Organizational Management; García-Álvarez, S., Atristain-Suárez, C., Eds.; EMERALD Group PUBL: London, UK, 2020; pp. 259-278. ISBN 183867974X.

18. Kansra, P. Awareness and Attitude of Management Students towards CSR. In National Seminar on Contemporary Issues in Management; Punjabi University Patiala: Patiala, India, 2014.

19. Teixeira, A.; Ferreira, M.R.; Correia, A.; Lima, V. Students' perceptions of corporate social responsibility: Evidences from a Portuguese higher education institution. Int. Rev. Public Nonprofit Mark. 2018, 15, 235-252. [CrossRef]

20. Vázquez, J.L.; Lanero, A.; Licandro, O. Corporate Social Responsibility and Higher Education: Uruguay University Students' Perceptions. Econ. Sociol. 2013, 6, 145-157. [CrossRef]

21. Larrán, M.; Andrades, J.; Herrera, J. An examination of attitudes and perceptions of Spanish business and accounting students toward corporate social responsibility and sustainability themes. Rev. Contab. 2018, 21, 196-205. [CrossRef]

22. Cockalo, D.; Djordjevic, D.; Besic, C.; Bogetic, S. Undergraduate business students' attitudes towards CSR and competitiveness of Serbian economy. JEMC 2015, 5, 12-20. [CrossRef]

23. Farcane, N.; Deliu, D.; Bureană, E. A Corporate Case Study: The Application of Rokeach's Value System to Corporate Social Responsibility (CSR). Sustainability 2019, 11, 6612. [CrossRef]

24. Haski-Leventhal, D. MBA Students Around the World and Their Attitudes towards Responsible Management: Second Annual Study. Available online: http:/ / citeseerx.ist.psu.edu/viewdoc/download?doi=10.1.1.395.27\&rep=rep1\&type=pdf (accessed on 15 November 2020). 
25. Carroll, A.B. The pyramid of corporate social responsibility: Toward the moral management of organizational stakeholders. Bus. Horiz. 1991, 34, 39-48. [CrossRef]

26. Falck, O.; Heblich, S. Corporate social responsibility: Doing well by doing good. Bus. Horiz. 2007, 50, 247-254. [CrossRef]

27. Carroll, A.B. Carroll's pyramid of CSR: Taking another look. Int. J. Corp. Soc. Responsib. 2016, 1, 1-8. [CrossRef]

28. Visser, W. Revisiting Carroll's CSR Pyramid an African Perspective. In Corporate Citizenship in Developing Countries: New Partnership Perspectives; Huniche, M., Pedersen, E.R., Eds.; Copenhagen Business School Press: Copenhagen, Denmark, 2006; ISBN 8763001411.

29. Lyra, F.R.; Barbosa De Souza, M.J.; Verdinelli, M.A.; Lana, J. Corporate social responsibility: Comparing different models. SRJ 2017, 13, 728-742. [CrossRef]

30. de Almeida, F.J.R. Responsabilidade Social das Empresas e Valores Humanos: Um Estudo Sobre a Atitude dos Gestores Brasileiros. Ph.D. Thesis, Escola Brasileira de Administração Pública e de Empresas, Rio de Janeiro, Brazil, 2007.

31. Aupperle, K.; Hatfield, J.D.; Carroll, A.B. Instrument Development and Application in Corporate Social Responsibility. AMPROC 1983, 1983, 369-373. [CrossRef]

32. Carroll, A.B. A Three-Dimensional Conceptual Model of Corporate Performance. Acad. Manag. Rev. 1979, 4, 497-505. [CrossRef]

33. Luck, D.J.; Rubin, R.S.; Wales, H. Marketing Research, 7th ed.; Prentice-Hall: Englewood Cliffs, NJ, USA, 1987 ; ISBN 0135578280.

34. Stanisz, A. Przystępny kurs statystyki. Z zastosowaniem STATISTICA PL na przykładach z medycyny; Wyd. 3, zm. i popr; StatSoft: Kraków, Poland, 2006; ISBN 978-83-88724-18-3.

35. Godos-Díez, J.-L.; Cabeza-García, L.; Fernández-González, C. Relationship between Corporate Social Responsibility (CSR) and Internationalisation Strategies: A Descriptive Study in the Spanish Context. Adm. Sci. 2018, 8, 57. [CrossRef] 